the very low incidence of catheter sepsis.-13,24 Current guidelines still do not address duration of PIV catheter placement in children because of the modest number of pediatric patients studied. Nonetheless, outcomes of the approximately 3,000 catheters studied to date provide a basis for the current practice of leaving PIV catheters in place until IV therapy is completed or a complication occurs. Additional studies in children should be performed to provide a more substantial basis for specific pediatric guidelines.

\section{REFERENCES}

1. Damen J, Van der Tweel I. Positive tip cultures and related risk factors associated with intravascular catheterization in pediatric cardiac patients. Crit Care Med 1988;16:221-228.

2. Nelson DB, Garland JS. The natural history of Teflon catheter-associated phlebitis in children. Am J Dis Child 1987;141:1090-1092.

3. Tully JL, Friedland GH, Baldini LM, Goldmann DA. Complications of intravenous therapy with steel needles and Teflon catheters. A comparative study. Am J Med 1981;70:702-706.

4. Raad II, Bodey GP. Infectious complications of indwelling vascular catheters. Clin Infect Dis 1992;15:197-208

5. Garland JS, Nelson DB, Cheah TE, Hennes HH, Johnson TM. Infectious complications during peripheral intravenous therapy with Teflon catheters: a prospective study. Pediatr Infect Dis J 1987;6:918-921.

6. Garland JS, Dunne WM Jr, Havens P, Hintermeyer M, Bozzette MA, Wincek $\mathrm{J}$, et al. Peripheral intravenous catheter complications in critically ill children: a prospective study. Pediatrics 1992;89(6 Pt 2):1145 1150 .

7. Batton DG, Maisels MJ, Appelbaum P. Use of peripheral intravenous cannulas in premature infants: a controlled study. Pediatrics 1982;70:487490.

8. Band JD, Maki DG. Steel needles used for intravenous therapy. Morbidity in patients with hematologic malignancy. Arch Intern $\mathrm{Med}$ 1980;140:31-34.

9. Maki DG, Ringer M. Evaluation of dressing regimens for prevention of infection with peripheral intravenous catheters. Gauze, a transparent polyurethane dressing, and an iodophor-transparent dressing. JAMA 1987;258:2396-2403.
10. Craven DE, Lichtenberg DA, Kunches LM, McDonough AT, Gonzalez MI, Heeren TC, et al. A randomized study comparing a transparent polyurethane dressing to a dry gauze dressing for peripheral intravenous catheter sites. Infect Control 1985;6:361-366.

11. Tager IB, Ginsberg MB, Ellis SE, Waish NE, Dupont I, Simchen E, et al. An epidemiologic study of the risks associated with peripheral intravenous catheters. Am I Epidemiol 1983;118:839-851.

12. Maki DG, Ringer M. Risk factors for infusion-related phlebitis with small peripheral venous catheters. A randomized controlled trial. Ann Intern Med 1991;114:845-854.

13. Centers for Disease Control and Prevention. Guideline for prevention of intravascular device-related infections. Infect Control Hosp Epidemiol 1996;17:438-473.

14. Maki DG, Weise CE, Sarafin HW. A semiquantitative culture method for identifying intravenous-catheter-related infection. $N$ Engl $J$ Med 1977;296:1305-1309.

15. Murray PR, Baron EJ, Pfaller MA, Tenover FC, Yolken RH, eds. Manual of Clinical Microbiology. 6th ed. Washington, DC: ASM Press; 1995.

16. Breslow NE, Day NE. Statistical Methods in Cancer Research, Vol 2-The Design and Analysis of Cohort Studies. London, England: IARC Scientific Publications; 1987:131-135.

17. Zeger SL, Liang KY. Longitudinal data analysis for discrete and continuous outcomes. Biometrics 1986;42:121-130.

18. Schlager TA, Hidde M, Rodger P, Germanson TP, Donowitz LG. Intravascular catheter colonization in critically ill children. Infect Control Hosp Epidemiol 1997;18:347-348.

19. Garland JS, Buck RK, Maloney P, Durkin DM, Toth-Lloyd S, Duffy M, et al. Comparison of $10 \%$ povidone-iodine and $0.5 \%$ chlorhexidine gluconate for the prevention of peripheral intravenous catheter colonization in neonates: a prospective trial. Pediatr Infect Dis $J$ 1995;14:510-516.

20. Hershey CO, Tomford JW, McLaren CE, Porter DK, Cohen DI. The natural history of intravenous catheter-associated phlebitis. Arch Intern Med 1984;144:1373-1375.

21. Centers for Disease Control Working Group. Guidelines for prevention of intravenous therapy-related infections. Infect Control 1981;3:62-79.

22. Bentley DW, Lepper MH. Septicemia related to indwelling venous catheter. JAMA 1968;206:1749-1752.

23. Harbin RL, Schaffner W. Septicemia associated with scalp-vein needles. South Med J 1973;66:638-640.

24. Maki DG, Band JD. A comparative study of polyantibiotic and iodophor ointments in prevention of vascular catheter-related infection. Am J Med 1981;70:739-744.

\title{
Quinolone-Resistant Strains of Escherichia coli
}

\section{Gina Pugliese, RN, MS Martin S. Favero, $\mathbf{P h D}$}

Aparicio and colleagues from the Hospital General Universitario de Alicante, Spain, evaluated the prevalence of quinolone-resistant strains of Escherichia coli in patient stools on admission and the characteristics of any nosocomial infections. Norfloxacin prophylaxis decreases the incidence of bacterial infections in high-risk cirrhotic patients, but may promote the development of quinolone-resistant gram-negative bacteria in stools and eventually lead to infections due to these bacteria. Eighty-three consecutively hospitalized cirrhotic patients were included in this prospective study. The presence of quinolone- resistant strains of $E$ coli in stools on admission and the characteristics of any nosocomial infections were recorded.

Fourteen (16.8\%) of 83 patients showed quinolone-resistant $E$ coli in stools (group I), and 69 did not (group II). Thirteen of 14 from group I $(92.8 \%)$ and $17(24.6 \%)$ of 69 from group II had received primary or secondary prophylaxis with norfloxacin $(P<.001)$. During hospitalization, 12 of 12 patients from group I and $25(37.8 \%)$ of 66 patients from group II underwent norfloxacin prophylaxis. Three bacterial infections in patients from group I, 3 from group II patients receiving norfloxacin, and 16 from group II patients not receiving norfloxacin were recorded $(P<.05)$. No infections due to quinolone-resistant $E$ coli were observed in patients colo- nized with these bacteria. Treatment with norfloxacin induced the development of quinolone-resistant $E$ coli in 6 $(42.8 \%)$ of 14 patients in a mean time of $18.5 \pm 9.8$ days.

The authors concluded that the development of quinolone-resistant strains of $E$ coli was significantly associated with previous administration of norfloxacin prophylaxis. However, this fact was not associated with an increased incidence of quinolone-resistant $E$ coli or other gram-negative infections.

FROM: Aparicio JR, Such J, Pascual S, Arroyo A, Plazas J, Girona $\mathrm{E}$, et al. Development of quinoloneresistant strains of Escherichia coli in stools of patients with cirrhosis undergoing norfloxacin prophylaxis: clinical consequences. I Hepatol 1999;31: 277-283. 